University of Nebraska - Lincoln

DigitalCommons@University of Nebraska - Lincoln

Faculty Publications, Department of Psychology

Psychology, Department of

April 2005

\title{
Future expectations of Brasilian street youth
}

\author{
Marcela Raffaelli \\ University of Nebraska-Lincoln, mraffaelli1@unl.edu \\ Silvia H. Koller \\ Universidade Federal do Rio Grande do Sul, Brasil
}

Follow this and additional works at: https://digitalcommons.unl.edu/psychfacpub

Part of the Psychiatry and Psychology Commons

Raffaelli, Marcela and Koller, Silvia H., "Future expectations of Brasilian street youth" (2005). Faculty Publications, Department of Psychology. 318.

https://digitalcommons.unl.edu/psychfacpub/318

This Article is brought to you for free and open access by the Psychology, Department of at DigitalCommons@University of Nebraska - Lincoln. It has been accepted for inclusion in Faculty Publications, Department of Psychology by an authorized administrator of DigitalCommons@University of Nebraska - Lincoln. 
Published in Journal of Adolescence 28:2 (April 2005; Homeless and Runaway Youth), pp. 249-262;

doi 10.1016/j.adolescence.2005.02.007

Copyright $(\odot 2005$ The Association for Professionals in Services for Adolescents Published by Elsevier Ltd.

Used by permission. http://www.sciencedirect.com/science/journal/01401971

Published online March 11, 2005.

\title{
Future expectations of Brasilian street youth
}

\author{
Marcela Raffaelli * $\ddagger$ and Silvia H. Koller ${ }^{\dagger}$ \\ * Department of Psychology and Institute for Ethnic Studies, University of Nebraska, \\ 238 Burnett Hall, Lincoln, NE 68588 0308, USA \\ ${ }^{+}$Universidade Federal do Rio Grande do Sul, Brasil \\ ‡Corresponding author. Tel.: 402 472-0737; fax: 402 472-4637; email: mraffaelli1@unl.edu
}

\begin{abstract}
Future expectations of youth surviving on the streets of Porto Alegre, Brasil, were examined. The sample consisted of 35 boys and 34 girls aged $10-18$ ( $M$ age 14.4) who participated in a sentence completion task and semi-structured interviews. Responses to two incomplete sentences regarding the future revealed a mismatch between hoped-for and expected events. When completing the sentence, "In the future, I hope..." the majority of youth gave optimistic (but generally non-specific) responses. In contrast, the sentence "For me, the future..." elicited more pessimistic responses. Few gender or age-related differences emerged. Findings are discussed in light of prior research with general populations of adolescents as well as studies of street youth. Taken as a whole, results suggest that life on the street shapes and constrains how youth see their futures. Implications of the findings for policy makers and practitioners are addressed.
\end{abstract}

\section{Introduction}

A major developmental task of the adolescent years is preparation for adult roles involving work and family (Havighurst, 1948/1974; Marcia, 1980). In modern societies, youth typically prepare for adult work roles through a variety of formal and informal experiences, including education, vocational training, and activities that allow them to explore their interests and abilities. 
Preparation for taking on adult family roles includes participating in different social groups, exploring romantic relationships, and renegotiating relationships with parents. These experiences provide a context for the development of future expectations-variously defined as goals, interests, or plans concerning the future (Sundberg, Poole, \& Tyler, 1983). For many adolescents, however, preparation for adult roles is hampered by economic instability and the lack of higher education and employment opportunities (Welti, 2002; Arnett, 2004). The situation is even more uncertain for children and adolescents who are growing up in the often hostile environment of city streets. Street youth experience limited opportunities to explore potential careers due to curtailed education and lack of formal training. Moreover, because many youth come from families characterized by financial hardship and psychosocial stresses (e.g., family violence, child abuse, economic exploitation of children; Hecht, 1998; De Antoni \& Koller, 2000a), their expectations regarding a future family may also be problematic. The goal of this paper is to examine future expectations in a sample of youth surviving on the streets of Porto Alegre, Brasil.

\section{Future expectations in general populations of adolescents}

From a theoretical perspective, expectations about the future are important because they serve as powerful motivators of current decisions (Nurmi, 1991). Moreover, the kinds of expectations that adolescents hold for their futures have been linked to psychosocial outcomes (McCabe \& Barnett, 2000). A large body of developmental theory and research has examined future expectations in general populations of adolescents around the world (see Nurmi, 1991, for review). Much of this research has been aimed at describing the content of life goals and examining differences attributable to age, gender, socioeconomic status, or nationality (e.g., Mönks, 1968; Sundberg et al., 1983; Poole \& Cooney, 1987; Nurmi, 1989; Nurmi, 1994). A more recent body of research based on the theory of possible selves (Markus \& Nurius, 1986) has examined discrepancies between what adolescents hope will happen to them, and what they really expect to occur. According to Yowell (2002), hoped-for-selves represent abstract wishes or fantasies that are largely unconnected to actual behavior; in contrast, expected selves are concrete and serve as guides for behavior and planning.

In a major review, Nurmi (1991) summarized results of empirical studies on adolescent future expectations. This review revealed consistencies in the content of adolescent expectations across numerous studies conducted in different countries and with adolescents from different backgrounds. When asked about their futures, adolescents tend to focus primarily on goals related to their profession, education, and family formation. Age-related differences have been consistently reported, with older adolescents being more likely to emphasize goals related to future careers (e.g., educational and occupational goals) and family, and less likely to mention leisure goals, than younger adolescents. Gender differences in the content of future expectations are also observed; in general, girls tend to focus on family goals and boys on occupational and educational goals. Only a handful of studies have examined contextual factors, including socioeconomic status and nationality. This research suggests that adolescents growing up in poverty tend to emphasize occupational goals whereas middle-class adolescents prioritize educational and leisure goals. For example, in a study of 15-year-olds in Singapore and Sydney, youth from low socioeconomic backgrounds listed more work-related events, whereas those from high socioeco- 
nomic backgrounds listed more education-related events (Poole \& Cooney, 1987). There is also evidence that other aspects of adolescents' life situation are linked to future expectations; e.g., Nurmi (1991) pointed out that delinquent youth tend to have future expectations that are less optimistic, less structured, and more self-oriented than those of non-delinquent youth.

Most of the research on future expectations has been descriptive; however, there is reason to believe that positive future expectations may enhance psychosocial adjustment. Researchers who study developmental pathways of youngsters in situations of adversity (including poverty, maltreatment, and community violence) find that youth who attain positive outcomes typically exhibit personal and social characteristics that differentiate them from their troubled peers (e.g., Garmezy \& Masten, 1994; Luthar, Cicchetti, \& Becker, 2000; Masten, 2001). Several of these studies have examined the role of future expectations as a key individual-level factor. For example, Werner \& Smith (1982) and Werner \& Smith (1992) reported that children who demonstrated resilience tend to have positive future expectations. Youngsters who can maintain a positive outlook despite difficult circumstances appear to benefit by formulating a life plan, defining means of achieving it, and identifying pathways to success (Walsh, 1996). Consistent with the view of future expectations as a protective factor (Hawley \& DeHaan, 1996), positive future expectations were associated with indicators of adjustment among urban children exposed to high levels of psychosocial stress (Wyman, Cowen, Work, \& Kerley, 1993). This body of literature highlights the developmental significance of future expectations during adolescence.

\section{Future expectations in street youth}

The literature on adolescent future expectations provides a point of departure for the current study, which was conducted with Brasilian street youth. The label of "street youth" encompasses children and adolescents seeking their survival in street settings, including youth who live at home and work on the street as well as youngsters who have left their families to live on their own (Hecht, 1998; Hutz \& Koller, 1999). Within the last 15 years, there has been a dramatic surge in social science studies of street youth (e.g., Felsman, 1989; Myers, 1989; Tyler, Tyler, Echeverry, \& Zea, 1991; Lusk, 1992; Aptekar, 1994; for reviews, see Connolly \& Ennew, 1996; Koller \& Hutz, 1996; Rizzini, 1996; Raffaelli, 1999). This research has generated rich descriptive information about the conditions in which street youth survive and about their psychosocial adjustment. Almost entirely absent, however, is information about how street youth make sense of their lives and think about their futures. One exception is work by Baker and Panter-Brick (2000), who described the "careers" of children and adolescents living and working on the streets of Kathmandu, Nepal. The aspirations of squatter and homeless street children are based on "commonly held ideas about adulthood, occupation, home and family" (Baker \& Panter-Brick, 2000, p. 174), yet are limited by children's lack of education and vocational training.

The general focus on youngsters' current situation is understandable, in light of the need to generate information that can be used to address immediate concerns and inform policy decisions. In many cities, youth who spend time on the street are at increased risk of negative developmental outcomes due to their often dangerous living situations and the violence they are exposed to on the street (Aptekar, 1994; Hecht, 1998; Raffaelli, 1999). As a result, a great deal of attention has been dedicated to addressing survival and human rights issues. At the same time, 
street youth are confronting the same developmental tasks as other adolescents, and the majority survive into adulthood. Therefore, it is important to understand factors that may be linked to positive developmental outcomes in this vulnerable population.

There is evidence to suggest that gaining an understanding of how street youth see their futures could provide insight into their long-term development. Research with adolescent girls in high-risk situations, including some who had lived on the street for part of their lives, revealed that girls who exhibited the highest levels of resilience had more structured life plans regarding work and family, and were optimistic about their ability to overcome their stressful life situations (De Antoni \& Koller (2000a) and De Antoni \& Koller (2000b); Cecconello, De Antoni, \& Koller, 2003). In a recent study involving a small sample of street boys, Neiva-Silva (2003) found that boys who used drugs had less positive expectations than those who did not use drugs; in turn, drug use appeared to be linked to having unstable family ties. Based on this research, a more indepth examination of future expectations of street youth appears warranted.

No published studies directly assessing the future expectations of Brasilian street youth have been identified, although ethnographic studies conducted in Brasil in recent years provide insight into how street youth think about themselves and their futures. An examination of daily life on the streets of one Brasilian city illustrated the challenges to developing a sense of competence and positive identity street youth face, given the negative messages they receive from the larger society (Diversi, Moraes, \& Morelli, 1999). In a study conducted in northeastern Brasil, Hecht (1998) described street youth as holding a "bourgeois dream of eventually marrying, working, becoming a homeowner, and having a couple of children" (p. 184). These expectations are similar to those described in general populations of youth; however, it was also apparent to Hecht that youth recognize the difficulty of attaining this dream, given their current reality. These studies suggest that thinking about the future may be troubling to street youth; however, because the topic was not explored systematically in either of these studies, it is impossible to get a full picture of the future expectations of street youth.

The current study builds on this prior research by describing how street youth think about their futures. A secondary goal was to examine age and gender differences in future expectations.

\section{Method}

\section{Setting}

The study was conducted in Porto Alegre, a mid-sized city (population 1.5 million) in southern Brasil. Porto Alegre is the capital of the state of Rio Grande do Sul and one of the largest cities in the southern region. There is a rich ethnic diversity among its inhabitants; the majority are of European and African ancestry, but Asian and indigenous groups are also represented, resulting in a large multiracial population. Although the southern region of Brasil has a comparatively high quality of life relative to other parts of the country, official statistics reveal that a substantial proportion of the population of Rio Grande do Sul is living in conditions of poverty (Instituto Brasileiro de Geografia e Estatística, 2003). For example, in 2000, the average head of household had 6.3 years of education, and just $61 \%$ of homes had "adequate" sanitation (11\% had no plumbing or sewage disposal system). Families with young children are disproportionately likely to be 
in poverty: among children aged 6 and under, $20 \%$ were in homes where the primary caregivers had less than 4 years of education; $42 \%$ were in homes where the primary caregivers earned less than two minimum salaries; and $44 \%$ were in homes with inadequate sanitation. This high level of poverty results in a substantial street population. Although no exact statistics exist, it is estimated that there are between 400 and 500 homeless street youth (i.e., children and adolescents who spend most of their time in street settings, frequent institutions set up to serve street youth, and have limited family contact) in Porto Alegre (Koller \& Hutz, 1996). Many other youth live at home but spend time working and playing on the streets of downtown Porto Alegre.

\section{Procedures}

An opportunity sample was obtained by recruiting youth in governmental and non-governmental agencies serving street children and adolescents (e.g., shelters, open houses providing meals and recreational activities). Similar recruitment strategies have been described in other studies of homeless youth, who are rarely found in contexts that permit random sampling (Hutz \& Koller, 1999; Matchinda, 1999). Following procedures approved by Institutional Review Boards at the co-Investigators' home universities, interviewers approached potential respondents, explained the study, and invited them to participate in two assessments: a sentence completion task and a semi-structured interview. All of the youth invited to participate in the study agreed to take part. Data collection was conducted in Portuguese by trained University students.

\section{Participants}

Sixty-nine youth (35 boys, 34 girls) aged 10-18 ( $M$ age 14.4, SD=1.9) completed the entire study and provided demographic information (nine others completed the sentence completion task but not the interview and were excluded from the current analyses). Over one-third (36\%) of the respondents were White; most were of Afro-Brasilian (41\%) or mixed/multi-racial (23\%) descent. Two-fifths (41\%) of the participants were not attending school, 30\% were in the formal educational system, and $29 \%$ attended alternative schools set up to serve youth who are no longer involved in the formal educational system.

As might be expected from the sampling strategy, all of the youths frequented institutions serving "street youth." When asked what they did during a typical day, youngsters said they attended school (48\%), played games or sports (26\%), worked (19\%), "hung out" (19\%), or begged $(6 \%)$ (categories are not mutually exclusively so percentages add up to over 100). Only a few youth said they spent time at their family home during either the day $(n=3)$ or night $(n=5)$, and about $20 \%$ went home on weekends. When asked where they typically slept, two-fifths (42\%) of the respondents said institutions, $26 \%$ the street, $7 \%$ both institutions and the street, $10 \%$ home only, and $14 \%$ some combination of home, street, and institutions.

Measures of future expectations

Three different aspects of future expectations were assessed. Two stems from the Sentence Completion Task for Street Children and Adolescents (Raffaelli et al., 2001) were used to elicit youngsters' hopes for the future ("In the future, I hope..." [no futuro, espero...]) as well as their general ex- 
pectations of the future ("For me, the future..." [para mim, o futuro...]). The sentence completion task included 24 items assessing different domains (e.g., the street, family) relevant for street youth. Interviewers worked in pairs, with one conducting the interview and the other writing down the responses. After the participant had responded to all the stems, the interviewer read back the responses and asked for an explanation of the answer, which was also noted down verbatim. Responses to the sentence stems were coded using inductively derived content coding schemes. Two coders working independently classified the responses and discrepancies between coders were resolved by a third coder or discussed by the coding team until a consensus was reached.

Responses to the two stems were coded into mutually exclusive categories that were organized into six overarching themes: career-related, family-related, self-focused, world betterment, negative, and indifferent/do not know; uncodable or missing responses were excluded from analysis. The coding categories, and examples of responses falling into each category, are presented in the results section as findings are described.

During the semi-structured interview, youth were asked the open-ended question, "What do you think is going to happen to you when you're 18 years old?" This question was asked to assess specific predictions for the future by providing a concrete anchor point that has personal meaning to most street youth. The 18th birthday is significant for two main reasons. First, 18 is the age at which Brasilian youth attain legal status as adults; thus, the 18th birthday symbolizes the loss of protected status for youth (Hecht, 1998). Second, at age 18, Brasilian young men have to fulfill their military service requirement (or seek an official exemption). Thus, for both boys and girls, the 18th birthday represents a major life transition. Open-ended responses to this question were coded for up to two expected events. A set of yes/no variables were created that indicated whether youth said they expected to be working, studying, establishing a family, doing military service, doing something else, or they did not know what they would be doing.

Analysis plan

Descriptive analyses (frequencies and crosstabulations by gender and age) were conducted. Age and gender-related differences in the distribution of categorical responses were evaluated using $\chi^{2}$ tests. For age analyses, the sample was divided into two groups roughly equivalent to "early adolescents" (10-14 year olds; $n=36,57 \%$ male) and "middle adolescents" (15-18 year olds; $n=33,43 \%$ male). Because of limited statistical power due to the small sample size, a cutoff of $p<.075$ was used in reporting results of statistical tests. Further, given that the primary goal of the paper is descriptive, patterns of responses are summarized even when group comparisons are not significant.

\section{Results}

Hopes for the future

\section{Overall patterns and illustrative quotes}

The distribution of responses to the sentence stem, "In the future, I hope..." is shown in Table 1. Over two-fifths of responses fell into the self-focused category. Fifteen of the youth voiced 
Table 1. Distribution of responses to sentence stem, "In the future, I hope..." by gender and overall

\begin{tabular}{llll}
\hline & Boys $(n=34)$ & Girls $(n=31)$ & All $(n=65)$ \\
\hline Career-related & $\mathbf{1 4 . 7}$ & $\mathbf{2 2 . 6}$ & $\mathbf{1 8 . 4}$ \\
Study & 2.9 & 6.5 & 4.6 \\
Work & 11.8 & 16.1 & 13.8 \\
Family-related & $\mathbf{2 0 . 6}$ & $\mathbf{2 5 . 8}$ & $\mathbf{2 3 . 0}$ \\
Family of origin & 5.9 & 12.9 & 9.2 \\
Own (future) family & 14.7 & 12.9 & 13.8 \\
Self-focused & $\mathbf{4 7 . 1}$ & 35.5 & $\mathbf{4 1 . 6}$ \\
Personal goals & 11.8 & 25.8 & 18.5 \\
Material possessions/status & 35.3 & 9.7 & 23.1 \\
Better world & $\mathbf{1 4 . 7}$ & $\mathbf{0 . 0}$ & $\mathbf{7 . 7}$ \\
Indifferent/ambivalent & $\mathbf{2 . 9}$ & $\mathbf{1 6 . 1}$ & $\mathbf{9 . 2}$ \\
\hline
\end{tabular}

Note: Figures are percentages. Four respondents either did not respond, or gave responses that were uncodable. $\chi^{2}$ test for gender differences $=8.87, \mathrm{df}=4, p<.075$.

a desire to obtain material possessions or social status (e.g., "to be rich"; "to have lots of cash"). Twelve of the youth named personal goals, which were typically non-specific; examples include the desire to have "a good life," "lots of luck," or "see my dreams come true." Five youth expressed the desire for a better world (e.g., "for peace," "improvement on the streets").

Work and family themes were also seen in youngsters' responses to this stem. Family-related themes were evident in nearly one quarter of responses, including desires related to a future family of their own (e.g., "make a happy family," "have a nice, romantic wedding") as well as their family of origin (e.g., "go back home," "meet the person I like most, my grandmother who's already dead"). Just under a fifth of responses involved career-related themes, with the majority of youth stating that they hoped "to be a worker" or "to get lots of jobs." A few respondents expressed the desire to study.

None of the responses were coded as negative, and just six (9.2\%) of the youth gave a response that was coded as indifferent or ambivalent (e.g., "not sure," "don't know”).

\section{Age and gender differences}

Gender differences in the distribution of the five major themes (shown in bold in Table 1) were marginally significant $\left(\chi^{2}=8.87, \mathrm{df}=4, p<.075\right)$. More girls than boys focused on career-related and family issues, and more boys than girls generated self-focused hopes. Within the overarching category of self-focused hopes, boys were disproportionately likely to name material/status goals, whereas girls were more likely to name personal goals. All of the youth who expressed the hope for a better world were boys. Finally, more girls than boys gave indifferent or ambivalent responses. Parallel analyses were conducted to examine age-related differences (not shown); no differences emerged $\left(\chi^{2}=.955, \mathrm{df}=4, p=.912\right)$. 
General expectations for the future

Overall patterns and illustrative quotes

The first set of analyses revealed that when asked about their hopes for the future, street youth (particularly boys) were quite optimistic, if rather vague. In marked contrast, when asked to complete the more specific sentence "For me, the future..." over half of the youth gave responses suggesting that they saw their future as uncertain (Table 2). Over two-fifths gave responses that were coded as indifferent or ambivalent (e.g., "will be a better or worse life" or said they did not know (e.g., "is unforeseeable"). A few youth gave unequivocally negative responses (e.g., "is nothing"). Among the remaining youth, the most common responses involved career-related themes (over one quarter), followed by self-focused responses. Only a handful voiced family-related expectations, and one youth mentioned world betterment.

Age and gender differences

Gender differences in overarching categories were examined (Table 2). Because of the small number of responses within cells, the self-focused and better world categories, and the indifferent/ambivalent and negative categories, were combined for statistical analyses. The $\chi^{2}$ test was not significant $\left(\chi^{2}=3.65, \mathrm{df}=3, p>.075\right)$. Similar analyses were conducted to examine age differences (not shown); again, no significant differences emerged $\left(\chi^{2}=3.08, \mathrm{df}=3, p>.075\right)$.

Specific predictions for the future

When asked directly "What do you think will happen to you when you're 18 years old?" nearly a third of respondents said they did not know, but the remaining youth generated specific

Table 2. Distribution of responses to sentence stem, "For me, the future..." by gender and overall

\begin{tabular}{llll}
\hline & Boys $(n=32)$ & Girls $(n=33)$ & All $(n=65)$ \\
\hline Career-related & 28.1 & 24.2 & 26.1 \\
Study & 12.5 & 12.1 & 12.3 \\
Work & 15.6 & 12.1 & 13.8 \\
Family-related & 6.2 & 3.0 & 4.6 \\
Family of origin & 3.1 & 0.0 & 1.5 \\
Own (future) family & 3.1 & 3.0 & 3.1 \\
Self-focused & 6.2 & 27.3 & 16.9 \\
Personal goals & 3.1 & 21.2 & 12.3 \\
Material possessions/status & 3.1 & 6.1 & 4.6 \\
Better world & 3.1 & 0.0 & 1.5 \\
Indifferent/ambivalent & 46.9 & 39.4 & 43.1 \\
Negative & 9.4 & 6.1 & 7.7 \\
\hline
\end{tabular}

Note: Figures are percentages. Four respondents either did not respond, or gave responses that were uncodable. $\chi^{2}$ for gender differences $=3.65, \mathrm{df}=3, p>.075$. 
Table 3. Specific expectations for the future ("What do you think will happen to you when you're 18 years old?") by gender and overall

\begin{tabular}{llll}
\hline & Boys $(n=36)$ & Girls $(n=33)$ & All $(n=69)$ \\
\hline Don't know & 31.4 & 29.4 & 30.4 \\
Work & 45.7 & $17.6^{*}$ & 31.9 \\
Military service & 40.0 & $0.0^{* *}$ & 20.3 \\
Study & 8.6 & 8.8 & 8.7 \\
Family & 2.9 & 8.8 & 5.8 \\
Other & 5.7 & $47.1^{* *}$ & 26.1 \\
\hline
\end{tabular}

Note: Figures indicate proportion of respondents giving each response. Each respondent could give up to two answers, so categories are not mutually exclusive.

Significant gender difference, based on $\chi^{2}$ statistic with continuity correction: ${ }^{*} p<.025 ;{ }^{* *} p<.0001$.

responses (Table 3). Several gender differences were noted in responses to this question. Boys were significantly more likely than girls to say they thought they would be working, and girls were more likely than boys to give "other" responses. The majority of the "other" responses reflected personal characteristics rather than an activity or occupations (e.g., "I'll be grown up," "I'll be fatter," "I'll be big"). Two-fifths of the boys said they thought they would be doing their military service at age 18. Few youth said they thought they would be studying or starting a family. There were no age differences in responses to this question.

\section{Discussion}

Adolescents growing up in conditions of urban poverty and homelessness face multiple challenges as they prepare for adult roles involving work and family. Prior research has suggested that the economic and social impoverishment that characterizes the families of origin of street youth may interfere with their life plans and expectations (Alves et al., 2002). Other work suggests that street youth aspire to become reintegrated into mainstream society as they grow older, but face challenges due to external constraints (Baker \& Panter-Brick, 2000). Given their family difficulties and lack of educational and economic opportunities, how do street youth construct a vision of their future? In the current paper, we explored this issue by examining different aspects of future aspiration. In our discussion, we describe the hopes and expectations of the youth in our sample, and discuss how results from this study differ from those reported in studies with general populations of adolescents.

When asked their hopes for the future, the homeless Brasilian boys and girls in our sample gave responses that were quite different from those reported in research with general populations of adolescents conducted in different countries. This is unlikely to be the result of different methodologies because varied approaches to the study of future expectations have yielded consistent results (Nurmi, 1991). In general populations, adolescents' future goals and expectations focus on education, work, and family (Poole \& Cooney, 1987; Nurmi, 1989; Greene, 1990). These same themes emerged when street youth were asked about their future hopes, but were 
not the predominant themes; instead, many youth expressed vague hopes regarding personal success and attainment of material possessions. Similarly, Hecht (1998) characterized street children's hopes for the future as far removed from their current reality. The vagueness in hopes for the future may stem from youngsters' realization that their goals are unlikely to be attainable. Indeed, when youth were asked to predict what they would be doing at age 18, few generated predictions that matched their hopes, suggesting a mismatch between hopes and expectations.

Mismatches between hopes and expectations are thought to be linked to developmental challenges (e.g., Yowell, 2002). In marked contrast to their expressed hopes, when asked to complete the stem, "For me, the future..." over half of the respondents gave indifferent, ambivalent, or negative responses. No comparable levels of ambivalence have been reported in the published literature on future expectations conducted with various populations of adolescents. For example, in a study of low-income African American young adolescents ( $M$ age 12.4 years), McCabe and Barnett (2000) reported that the proportion giving vague (e.g., "don't know," "it will be good") responses ranged from $1 \%$ for career expectations to $27 \%$ for family/romance expectations. Furthermore, fewer than $2 \%$ said that success was "very unlikely" and relatively few youth reported no positive expectations related to a career $(1 \%)$, family $(14 \%)$ or romance $(21 \%)$. The lack of optimism evident in our sample is likely related to respondents' life situation. Being on the street exposes youth to risks including violence, drug use, and conflict with police (Campos, Raffaelli, Ude, Greco, \& Ruff, 1994; Hecht, 1998; Diversi et al., 1999; Raffaelli, 1999; Neiva-Silva \& Koller, 2003). In his review, Nurmi (1991) concluded that delinquent youth (who, it can be inferred, are in situations of increased risk) tend to have less optimistic and less structured expectations that non-delinquent youth. Similarly, Brasilian street boys who used drugs had less positive expectations than those who did not use drugs (Neiva-Silva, 2003). In general, the findings suggest a troubling lack of perceived future opportunities among street youth. The mismatch between hopes and expectations should be further explored in future research, and the implications of this mismatch for youngsters' long-term well-being examined.

Prior research on future expectations conducted in general populations of adolescents has revealed consistent gender differences, with girls emphasizing family-related expectations, and boys emphasizing occupational and educational goals. In the current study, few gender-related differences emerged in responses to the two sentence completion stems assessing future hopes and expectations. There are several possible explanations for this finding. One is that both female and male street youth prioritize goals that will promote their survival, reflecting the reality of their situation. In keeping with this interpretation, past research has linked economic necessity to high levels of work-related expectations among general populations of Indian girls as compared to American girls (Mehta, Rohila, Sundberg, \& Tyler, 1972). Another possibility is that expectations regarding a future family are marked by negative experiences in street children and adolescents' family of origin (Raffaelli, 1997; Raffaelli et al., 2000; De Antoni \& Koller, 2000b). Prior research has shown that families influence future orientation in important ways, including serving as a model for intimacy (Nurmi, 1991). The lack of a positive model for family life may make it difficult for street youth to envision a specific family future. This possibility represents an important avenue of future research on street youth's future expectations.

Significant gender differences did emerge when street youth were asked what they thought would happen to them when they turned 18. Two-fifths of the boys said they expected to be do- 
ing military service, which provides a socially accepted avenue for integrating into mainstream society. The military offers some hope of a career, with steady (even if not generous) income, and may be seen as a way of escaping from the street. However, because the majority of boys did not mention military service when responding to the open-ended items regarding their hopes and expectations, it is unclear to what extent entering the military reflects a personal goal (as opposed to a societal expectation). Because young women are not expected to perform military service, there is no comparable career path open for girls. When asked this specific question, few girls said they would be involved with work, education, or a family. Additional research is needed to understand how impoverished girls surviving on the street perceive their future options.

Anticipated age differences in future expectations did not emerge, despite consistent reports of age-related shifts in the content of expectations from early to middle adolescence (Nurmi (1991) and Nurmi (1994)). This is likely to reflect a lack of developmentally-appropriate opportunities on the street. Unlike general populations of adolescents, who are typically exposed to age-graded experiences in educational, vocational, and family settings, most street youth work at unskilled jobs (e.g., selling newspapers, shining shoes, washing cars), have limited family contact, and are typically not involved in the formal educational system (Campos et al., 1994). Diversi et al. (1999) posited that limited opportunities on the street may result in street youth thinking that they have "no future, no room in mainstream society" (p. 31; see also Baker \& Panter-Brick, 2000). The lack of perceived life options is likely to become more problematic as street children and adolescents grow up.

This study has a number of limitations that should be kept in mind when considering the results. One limitation is that our research was conducted in a single city, and the situation of street youth varies both within and across countries. A second limitation is that the sample was not randomly selected and may have differed systematically from the general population of street youth. The use of venue-based recruitment also limits sample generalizability, as youth who do not attend institutions may differ from those who do. A third limitation is that the larger study from which these data were derived was not intended to study future expectations, so only a small number of items were available for analysis. Future research can address these limitations by examining future expectations in representative samples of homeless youth recruited from multiple geographic locations.

The current study takes a first step in providing a systematic description of the future expectations of children and adolescents surviving on the street. The lack of educational and vocational opportunities for impoverished Brasilian youth has been noted previously (Rizzini, Barker, \& Cassaniga, 2002; Welti, 2002), and the current study suggests that street youth are all too aware of that lack (Alves et al., 2002). The challenge policy makers and practitioners face is how to provide street youth with alternative visions of the future, given their present conditions. Developmental researchers can contribute to this goal by identifying individual, social, and contextual factors that support the formation of positive future expectations among homeless and impoverished youth.

\section{Acknowledgments}

This research was supported by grants to Silvia H. Koller and her students at the Universidade Federal do Rio Grande do Sul from CNPq (520140/97-4), FAPERGS (Grant No. 97/0075.0), 
PET/CAPES, and PROPESQ/UFRGS; and by grants to Marcela Raffaelli from the University of Nebraska Research Council, Institute for Ethnic Studies, and Office on International Affairs. The authors acknowledge the research assistance of the Center for the Study of Street Youth (CEPRUA) team; the cooperation of agencies serving street youth; and - most importantly-the participating youth themselves. Address correspondence to Marcela Raffaelli, Department of Psychology and Institute for Ethnic Studies, 238 Burnett Hall, University of Nebraska, Lincoln, NE 68588-0308,mraffaelli1@unl.edu.

\section{References}

Alves et al. (2002): P. B. Alves, S. H. Koller, M. Silva, C. Santos, A. Silva, C. Reppold, and L. Prade, Atividades cotidianas de crianças em situação de rua [Daily activities of children in street situations], Psicologia: Teoria e Pesquisa 18 (2002), pp. 135-157.

Aptekar (1994): L. Aptekar, Street children in the developing world: A review of their condition, Cross-Cultural Research 28 (1994), pp. 195-224.

Arnett (2004): J. A. Arnett, Adolescence and emerging adulthood: A cultural approach (2nd ed.), Prentice-Hall, Upper Saddle River, NJ (2004).

Baker \& Panter-Brick (2000): R. Baker and C. Panter-Brick, A comparative perspective on children's "careers" and abandonment in Nepal. In: C. Panter-Brick and M. T. Smith, Editors, Abandoned children, Cambridge University Press, Cambridge, UK (2000), pp. 161-181.

Campos, Raffaelli, Ude, Greco, \& Ruff et al. (1994): R. Campos, M. Raffaelli, W. Ude, M. Greco, and A. Ruff, et al., Social networks and daily activities of street youth in Belo Horizonte, Brazil, Child Development 65 (1994), pp. 319-330.

Cecconello, De Antoni, \& Koller (2003): A. M. Cecconello, C. De Antoni, and S. H. Koller, Práticas educativas, estilos parentais e abuso físico [Educational practices, parenting styles, and physical abuse], Psicologia Em Estudo 8 (2003), pp. 45-54.

Connolly \& Ennew (1996): M. Connolly and J. Ennew, eds.. Children out of place: Special issue on working and street children. Childhood: A Global Journal of Child Research, 3(2).

De Antoni \& Koller (2000a): C. De Antoni and S. H. Koller, A visão de família entre as adolescentes que sofreram violência intrafamiliar [Family perceptions among adolescents who experienced family violence], Estudos de Psicologia (Natal) 5 (2000), pp. 347-382.

De Antoni \& Koller (2000b): C. De Antoni and S. H. Koller, Vulnerabilidade e resiliência familiar: um estudo com adolescentes que sofreram maus tratos intrafamiliares [Family vulnerability and resilience: a study with adolescents who experienced abuse within the family], Psico 31 (2000), pp. 39-66.

Diversi, Moraes, \& Morelli (1999): M. Diversi, N. Moraes, and M. Morelli, Daily reality on the streets of Campinas, Brazil. In: M. Raffaelli and R. Larson, Editors, Homeless and working youth around the world: Exploring developmental issues. New Directions in Child Development Vol. 85, Jossey-Bass, San Francisco (1999), pp. 19-34.

Felsman (1989): K. Felsman, Risk and resiliency in childhood: The lives of street children. In: T. Dugan and R. Coles, Editors, The child in our times: Studies in the development of resiliency, Brunner/Mazel, New York (1989), pp. 56-80.

Garmezy \& Masten (1994): N. Garmezy and A. Masten, Chonic adversities. In: M. Rutter, E. Taylor, and L. Herson, Editors, Child and adolescent psychiatry, Blackwell, Oxford, UK (1994), pp. 191-207.

Greene (1990): A. L. Greene, Great expectations: Constructions of the life course during adolescence, Journal of Youth and Adolescence 15 (1990), pp. 289-306.

Havighurst (1948/1974): R. J. Havighurst, Developmental tasks and education (3rd ed.), McKay, New York (1948/1974). 
Hawley \& DeHaan (1996): D. Hawley and L. DeHaan, Toward a definition of family resilience: Integrating life span and family perspectives, Family Process 35 (1996), pp. 283-298.

Hecht (1998): T. Hecht, At home in the street: Street children of Northeast Brazil, Cambridge University Press, New York (1998).

Hutz \& Koller (1999): C. S. Hutz and S. H. Koller, Methodological and ethical issues in research with street children. In: M. Raffaelli and R. Larson, Editors, Homeless and working youth around the world: Exploring developmental issues. New directions for child and adolescent development Vol. 85, Jossey-Bass, San Francisco, CA (1999), pp. 59-70.

Instituto Brasileiro de Geografia e Estatística (2003): Instituto Brasileiro de Geografia e Estatística. (2003). Indicadores Sociais Municipais-2000 [Municipal social indicators-2000] (Tables 15, 16, 19). Downloaded on May 13, 2003, from http://www.ibge.gov.br

Koller \& Hutz (1996): S. H. Koller and C. Hutz, Meninos e meninas em situação de rua: Dinâmica, diversidade e definição [Boys and girls in street situations; Dynamics, diversity and definition], Coletâneas da ANPEPP $\mathbf{1}$ (1996), pp. 11-34.

Lusk (1992): M. Lusk, Street children of Rio De Janeiro, International Social Work 35 (1992), pp. 293-305.

Luthar, Cicchetti, \& Becker (2000): S. S. Luthar, D. Cicchetti, and B. Becker, The construct of resilience: A critical evaluation and guidelines for future work, Child Development 71 (2000), pp. 543-562.

Marcia (1980): J. Marcia, Identity in adolescence. In: J. Adelson, Editor, Handbook of adolescent psychology, Wiley, New York (1980), pp. 156-187.

Markus \& Nurius (1986): H. Markus and P. Nurius, Possible selves, American Psychologist 41 (1986), pp. 954-969.

Masten (2001): A. S. Masten, Ordinary magic: Resilience processes in development, American Psychologist 56 (2001), pp. 227-238.

Matchinda (1999): B. Matchinda, The impact of home background on the decision of children to run away: The case of Yaounde city street children in Cameroon, Child Abuse \& Neglect 23 (1999), pp. 245-255.

McCabe \& Barnett (2000): K. McCabe and D. Barnett, First comes work, then comes marriage: Future orientation among African American young adolescents, Family Relations 49 (2000), pp. 63-72.

Mehta, Rohila, Sundberg, \& Tyler (1972): P. H. Mehta, P. K. Rohila, N. D. Sundberg, and L. E. Tyler, Future time perspective of adolescents in India and the United States, Journal of Cross-Cultural Psychology 3 (1972), pp. 293-302.

Mönks (1968): F. Mönks, Future time perspective in adolescents, Human Development 11 (1968), pp. 107-123.

Myers (1989): W. Myers, Urban working children: A comparison of four surveys from South America, International Labour Review 128 (1989), pp. 321-335.

Neiva-Silva (2003): Neiva-Silva, L. (2003). Future expectations of street boys: An auto-photographic study. Unpublished Master's thesis, Universidade Federal do Rio Grande do Sul.

Neiva-Silva \& Koller (2003): L. Neiva-Silva and S. H. Koller, A rua como contexto de desenvolvimento [The street as a developmental context]. In: E. Lordelo, A. Carvalho and S. Koller, Editors, Infância brasileira e contextos de desenvolvimento [Brasilian childhood and development contexts] Vol. 1, Casa do Psicólogo, São Paulo, Brasil (2003), pp. 205-230.

Nurmi (1989): J. E. Nurmi, Development of orientation to the future during early adolescence: A four year longitudinal study and two cross-sectional comparisons, International Journal of Psychology 24 (1989), pp. 195-214.

Nurmi (1991): J. E. Nurmi, How do adolescents see their future? A review of the development of future-orientation and planning, Developmental Review 11 (1991), pp. 1-59.

Nurmi (1994): J. E. Nurmi, The development of future-orientation in a life-span context. In: Z. Zaleski, Editor, Psychology of future orientation, Towarzystwo Naukowe KUL, Lublin (1994), pp. 63-74.

Poole \& Cooney (1987): M. E. Poole and G. H. Cooney, Orientations to the future: A comparison of adolescents in Australia and Singapore, Journal of Youth and Adolescence 17 (1987), pp. 129-151.

Raffaelli (1997): M. Raffaelli, Family situation of street youth in Latin America: A cross-national review, International Social Work 40 (1997), pp. 89-100. 
Raffaelli (1999): M. Raffaelli, Street youth in Latin America: A developmental review, InterAmerican Journal of Psychology 32 (1999), pp. 7-28.

Raffaelli et al. (2001): M. Raffaelli, S. H. Koller, D. R. Bandeira, C. Reppold, M. Kuschick and D. Dani, How do street youth experience "the street"?, Childhood: A Global Journal of Child Research 8 (2001), pp. 396-415.

Raffaelli et al. (2000): M. Raffaelli, S. H. Koller, C. Reppold, M. Kuschick, F. M. B. Krum, and D. R. Bandeira, Gender differences in Brazilian street youth's family circumstances and experiences on the street, Child Abuse and Neglect 24 (2000), pp. 1431-1441.

Rizzini (1996): I. Rizzini, Street children: An excluded generation in Latin America, Childhood: A Global Journal of Child Research 3 (1996), pp. 215-234.

Rizzini, Barker, \& Cassaniga (2002): I. Rizzini, G. Barker, and N. Cassaniga, From street children to all children: Improving the opportunities of low-income urban children and youth in Brazil. In: M. Tienda and W. J. Wilson, Editors, Youth in cities: A cross-national perspective, Cambridge University Press, Cambridge, UK (2002), pp. 113-137.

Sundberg, Poole, \& Tyler (1983): N. Sundberg, M. Poole, and E. Tyler, Adolescents' expectations of future events-A cross-cultural study of Australians, Americans, and Indians, International Journal of Psychology 18 (1983), pp. 415-427.

Tyler, Tyler, Echeverry, \& Zea (1991): F. B. Tyler, S. L. Tyler, J. J. Echeverry, and M. C. Zea, Making it on the streets in Bogatá: A psychosocial study of street youth, Genetic, Social, and General Psychology Monographs 117 (1991), pp. 395-417.

Walsh (1996): F. Walsh, The concept of family resilience: Crisis and challenge, Family Process 35 (1996), pp. 261-281.

Welti (2002): C. Welti, Adolescents in Latin America: Facing the future with skepticism. In: B. B. Brown, R. W. Larson and T. S. Saraswathi, Editors, The world's youth: Adolescence in eight regions of the globe, Cambridge University Press, Cambridge, UK (2002).

Werner \& Smith (1982): E. E. Werner and R. S. Smith, Vulnerable but invincible: A study of resilient children, McGraw-Hill, New York (1982).

Werner \& Smith (1992): E. E. Werner and R. S. Smith, Overcoming the odds: High risk children from birth to adulthood, Cornell University Press, New York (1992).

Wyman, Cowen, Work, \& Kerley (1993): P. A. Wyman, E. L. Cowen, W. C. Work, and J. H. Kerley, The role of children's future expectations in self-system functioning and adjustment to life stress: A prospective study of urban at-risk children, Development and Psychopathology 5 (1993), pp. 649-661.

Yowell (2002): C. M. Yowell, Dreams of the future: The pursuit of education and career possible selves among ninth grade Latino youth, Applied Developmental Science 6 (2002), pp. 62-72. 